\title{
The Origin of the Endodermis in the Stem of Hippuris.
}

BY

\author{
KATE BARRATT, B.Sc., \\ Demonstrator in Botany, Imperial College of Science and Technology, London.
}

With six Figures in the Text.

THE question of the three germinal layers exhibited by the stem 1 and root of Dicotyledons is a very old one, and has been the subject of investigation by many botanists. The idea that these three developing layers were the initials of definite tracts of tissue of the adult plant was first put forward by Hanstein. He supposed that of these three layers or histogens, the dermatogen gave rise to the epidermis, the periblem to the cortex, and the plerome to the central cylinder.

The fact that in the adult organs the innermost layer of the parenchymatous tissue surrounding the central cylinder is frequently differentiated by special characters has given to this layer, the endodermis, a special significance. The reason that it has acquired so much importance is that it has generally been regarded as the innermost layer of the cortex and developed from the innermost layer of the periblem, forming thus the boundary of the stele.

The importance of the endodermis as a morphological unit thus obviously depends on the uniformity of its mode of origin. This was realized by Schoute (1), who in I902 published a general review of the stelar theory, and incidentally made a critical examination of a number of stems and roots. He showed that the majority of species examined exhibited a well-marked endodermis. The origin of this layer from the apical tissue of the stem was investigated in the case of only six species, in some of which no distinction between periblem and plerome could be made out. Among the plants examined was Hippuris vulgaris, in the stem of which the apical structure is so clear that it has become a classical type for use in the laboratory.

Schoute, using series of transverse and longitudinal sections, traced the history of the development of the tissues from the apex to the mature part of the plant, and was led to the conclusion that here not only the endodermis, but several other layers of the cortex were derived from the plerome.

[Annals of Botany, Vol. XXX. No. CXVII. January, 1916.] 
This observation was directly opposed to the generally accepted idea of the origin of the tissues of Hippuris put forward by Sanio (2), according to which the endodermis was derived from the innermost periblem layer.

Since Schoute's observation has so far received no independent confirmation, a re-examination of the critical case of Hippuris seemed desirable, and material was therefore collected in the spring of I9I4 and I9I5. Schoute's methods of investigation were closely followed. Stem apices were selected from shoots of various sizes, care being expended to choose only straight ones. These were embedded and cut in series of transverse sections up to within a distance of about $100 \mu$ from the apex. The block was then rotated at right angles, and the remainder of the apex cut in a longitudinal series.

The advantage of this method is apparent. A median longitudinal section through the apex shows very clearly the distinction between the periblem and plerome, which is made evident by the small number and extreme regularity of the layers of periblem cells which form a series of caps covering the central column of plerome, in which the cells are less regularly arranged. In transverse sections the distinction is not so clear in this region, and the use therefore of longitudinal sections through the extreme apex of a stem of which the lower part is cut transversely, enables one to determine the exact number of periblem layers concerned in the origin of the mature tissues.

It is thus possible to trace with certainty the critical layer, the innermost of the periblem, and to identify the structure derived from it.

In order to be quite certain about the position of the delicate cell-walls of the developing tissues, it is necessary to clear away the cell-contents, and this can only be done satisfactorily by the use of eau de javelle on the sections. The clearing agents failed to penetrate the fixed material in bulk, even after the lapse of several days; on the other hand, the fresh material, though sufficiently cleared, was unsatisfactory because the cell-walls were also affected, losing their original firm contour, and in some cases actually breaking down. In order to be able to use eau de javelle on serial sections, it was necessary to employ a fixative other than albumen; water alone, collodion, and collodion with clove oil were tried, and a mixture of the latter in the proportion of $\mathrm{I}: 3$ was found most satisfactory. With this fixative it is necessary, first, to float out the sections on water and then to transfer them to a slide smeared with the mixture. It is essential to have absolutely clean slides and to use fixative recently made up.

Of the many different stains employed, polychrome methylene blue gave the best results. It is, however, difficult to keep sufficient stain in the sections owing to its tendency to wash out in alcohol, unless the sections are mordanted after staining by placing them for a few minutes in a Io per cent. solution of ammonium molybdate. 
The advantages of polychrome methylene blue are twofold ; it is a very quick and easily controlled stain, and it differentiates well. The walls of the cells lining the air-passages stain differently from the others, and are thereby easily distinguished even in longitudinal sections.

The structure of the apex of the stem as seen in median longitudinal section (Fig. I) exhibits an arrangement of cell-layers which follows diagrammatically the scheme set forth for stem apices in general. The outside is clothed by a single layer of regularly arranged cells, which constitutes a typical dermatogen. Within this, in the specimen figured, are five regular layers of cells forming the periblem. The cells of these differ little in form from those of the dermatogen. Within these, the cells of the plerome are more irregularly arranged, owing to the fact that they divide by both periclinal and anticlinal walls.

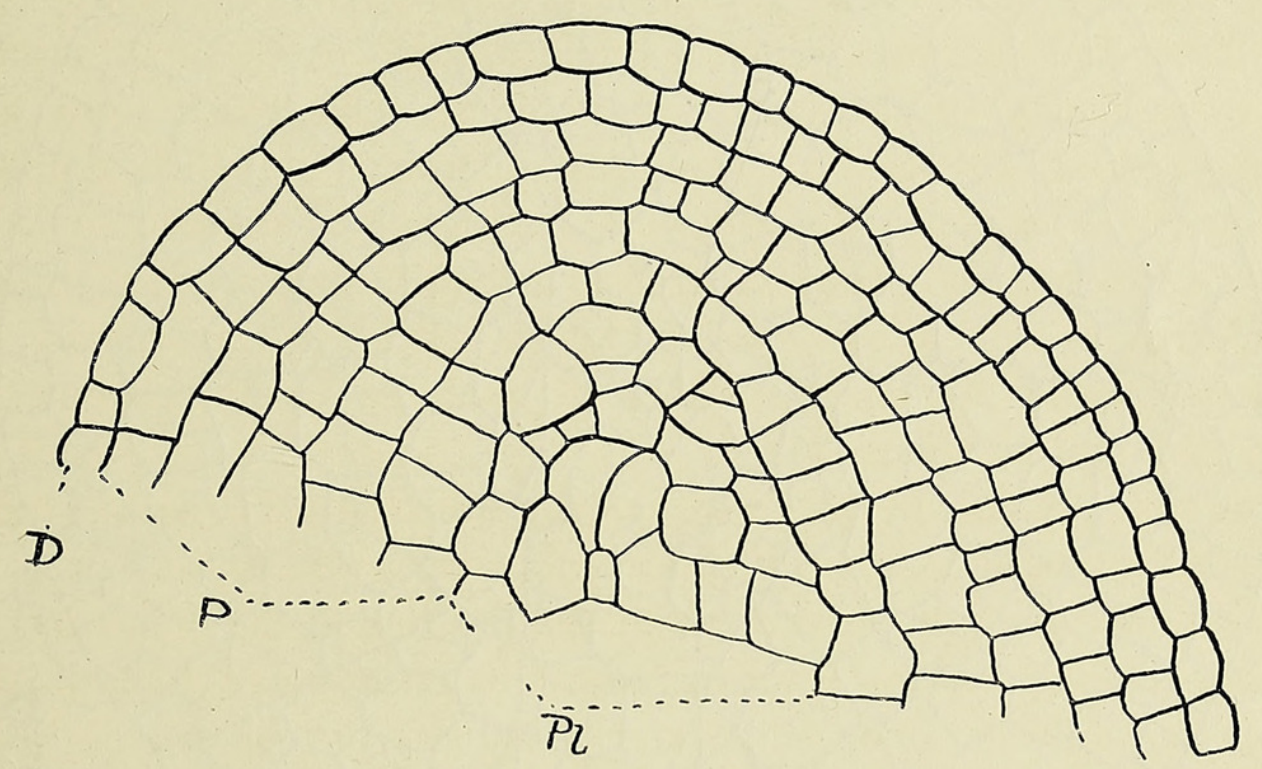

FIG. I. Longitudinal section of tip of stem of Hippuris vulgaris. $d$, dermatogen; p, periblem ; $p l$, plerome.

There is considerable variation in the size of the stem apices, and the number of periblem caps in the material examined varies from three to six. The general arrangement in other respects is quite consistent.

On turning to the transverse series and examining the first section (Fig. 2) it is a simple matter to interpret the layers of cells in terms of the longitudinal section. In some cases there is more difference between the size of cells of the periblem and those of the plerome than appears in the specimen figured. This difference becomes more pronounced as the sections are traced further down the stem. The cells of the plerome at an early stage divide rapidly by walls in all directions, thus producing a large number of small cells. The method of division is fairly regular. One cell divides into two, and these again divide independently by walls nearly at right angles, thus forming groups of four cells. These groups frequently 
continue segmenting, but it is generally possible, for quite a long time, to trace the outlines of these groups which originate from separate initials. The cells of the periblem do not divide so early, but enlarge to keep pace with the increasing bulk of plerome, and later divide by anticlinal walls, thus preserving the original number of layers.

The air-channels begin to form in the periblem as intercellular spaces at the angles between cells of different layers. As a result, one finds rings of small air-spaces appearing between successive layers of periblem cells.

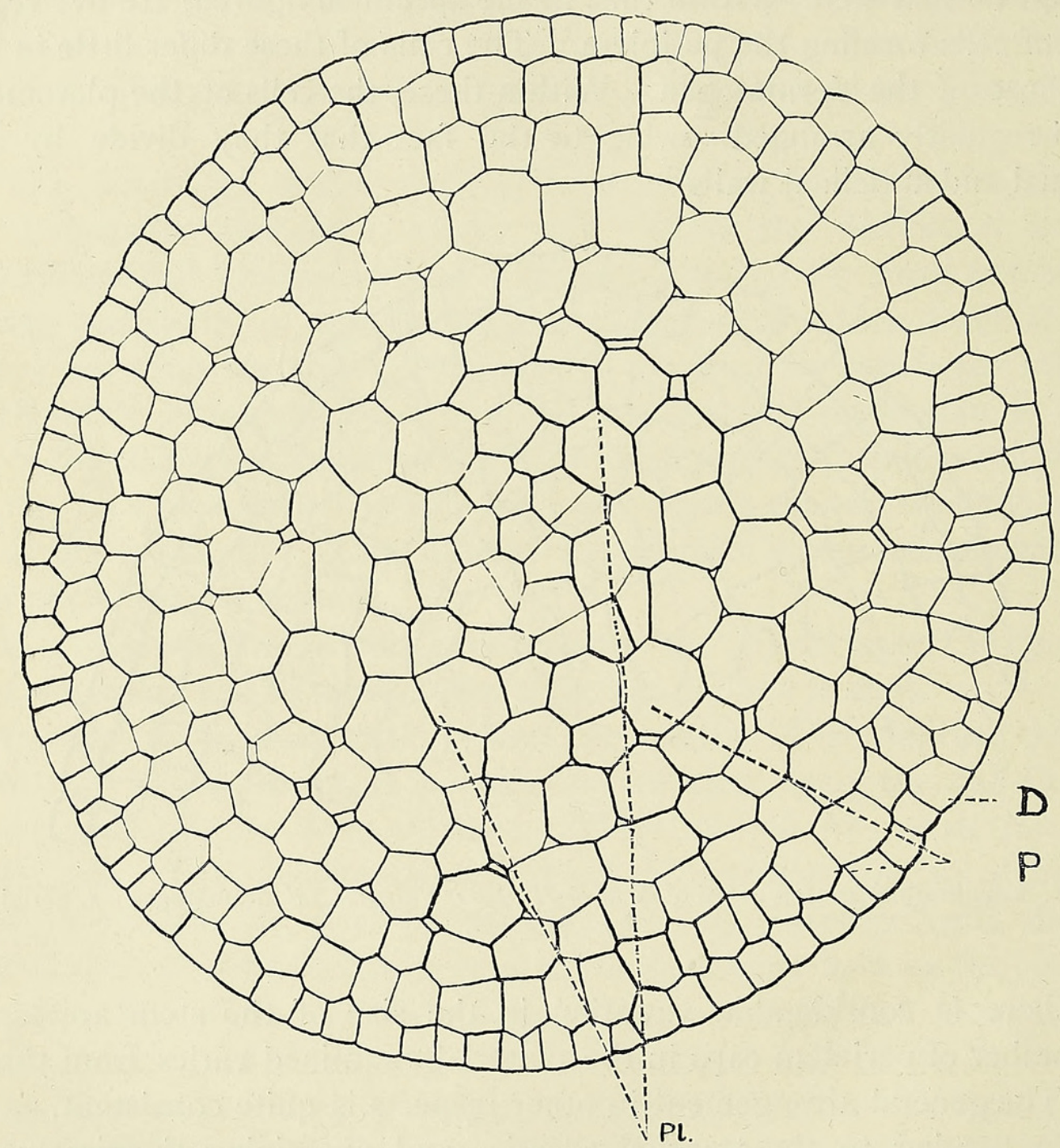

FIG. 2. Transverse section of same tip at region where the longitudinal section ends.

Such spaces are never found between the dermatogen and the first layer of the periblem; moreover, the ring of canals between the first and second periblem layers develops a little later than the ones within. As can be seen by reference to Fig. 3, there are four rings of canals developing.

At this stage the cells of the periblem begin to divide, and the subsequent arrangement of the cortical cells and air-canals is dependent on the direction in which these periblem cells segment. The innermost layer becomes divided by periclinal walls which are laid down in such a way as to 
abut upon an air-space at either end. The relative position of the original cells is preserved, as very little growth of the daughter-cells takes place for some time subsequent to the division (Fig. 3). In the outer layers the original cells may undergo subdivision into two or three, rarely more. The walls may be laid down in any direction, which is however determined by the position of neighbouring air-canals, since the ends of these walls invariably abut upon these passages. Thus at this stage every intercellular space is a centre from which a varying number of walls radiate (Figs. 3, 4). With the increase in size of the stem which now follows, the cells of the develop-

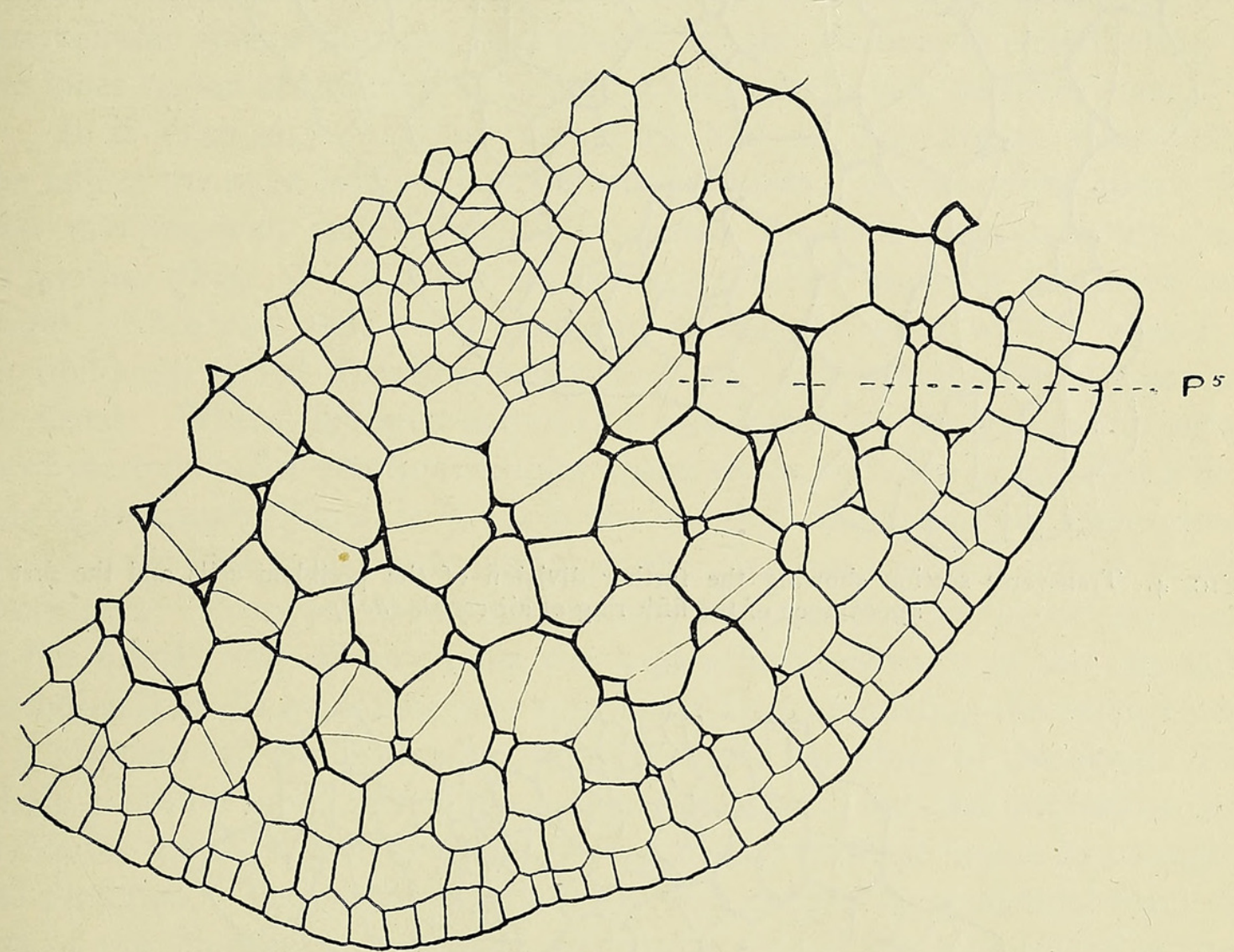

FIG. 3. Transverse section showing the innermost layer of periblem after the division into inner and outer cells. $p^{5}$, innermost periblem layer.

ing cortex undergo further subdivision, whilst at the same time the intercellular spaces enlarge enormously, owing to the rapid growth of these cells which surround, and eventually form single chains of cells separating them.

The development of the system of intercellular spaces just described serves to differentiate, very markedly in the young stem, the nodes and internodes, since the air-canals are only developed in the latter.

In the young nodes, on the other hand, cell-division takes place to a greater extent than in the internodes, first in connexion with the formation of the leaf-rudiments, secondly with the laying down of the pro- 


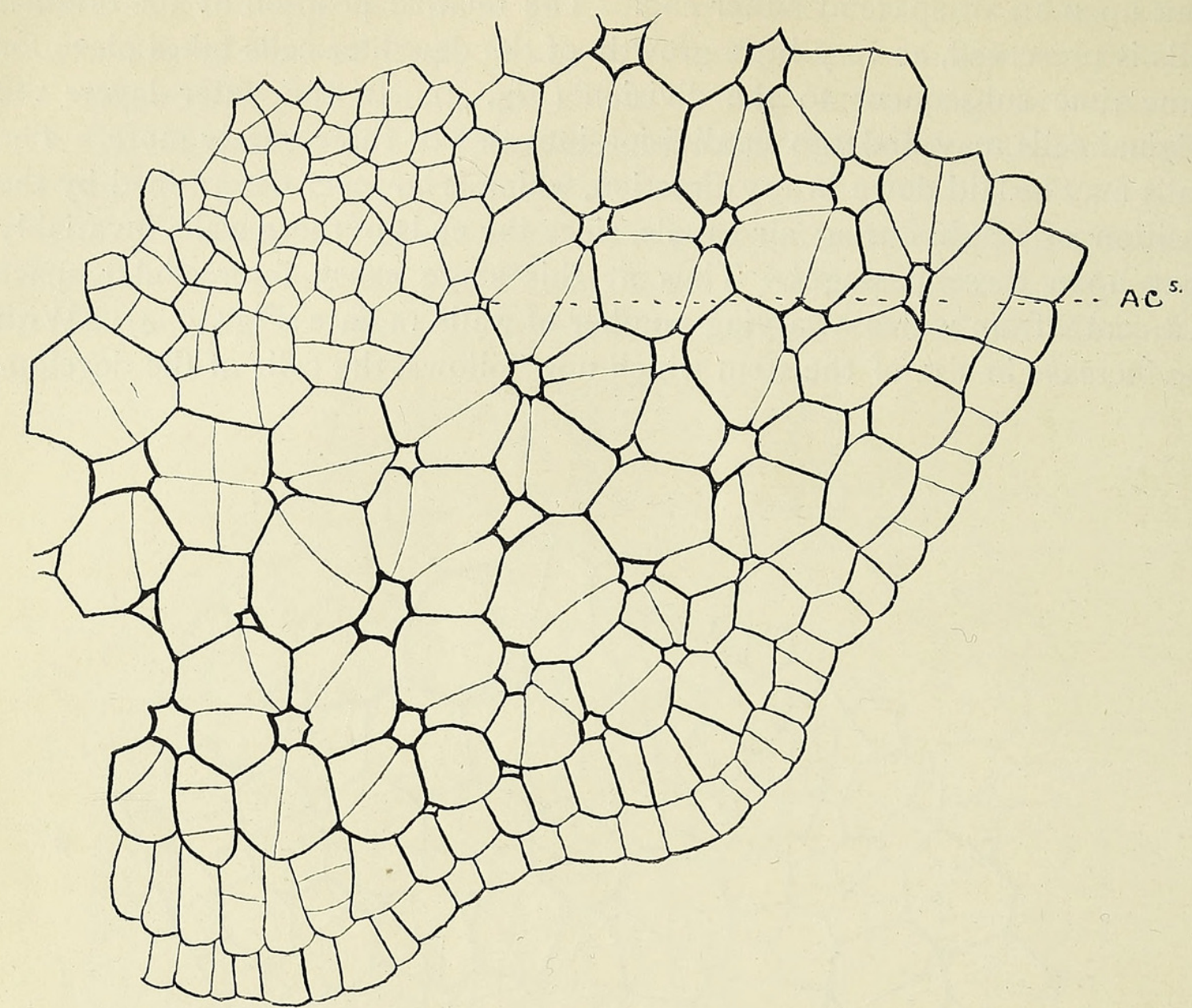

FIG. 4. Transverse section showing the further division of the periblem cells and the first appearance of the fifth ring of air-canals $\left(a c .^{5}\right)$.

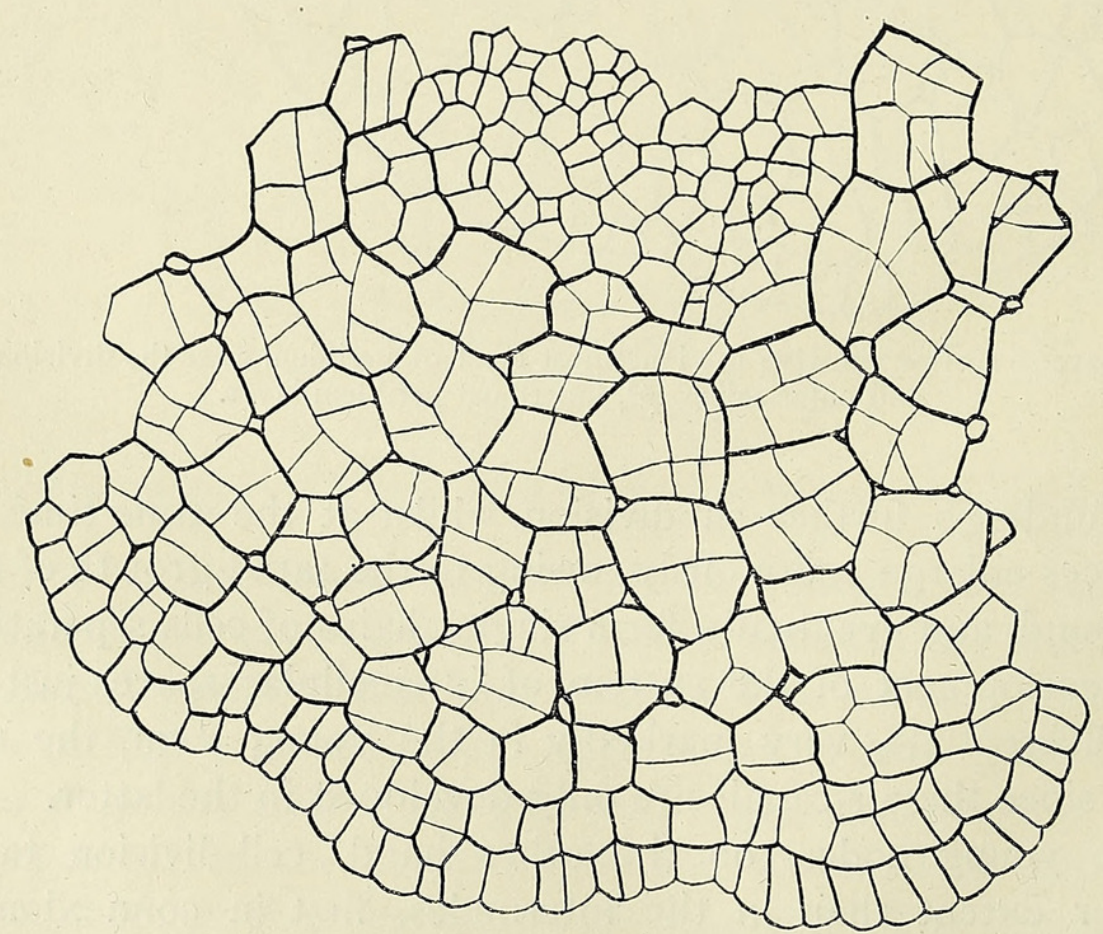

FIG. 5. Transverse section in the region of a node, about the same level as Fig. 4. 
cambial strands of the leaf-traces, and thirdly to keep pace with the rapid increase in size of the young cortex consequent upon the formation of the air-canals in the internodes. For this reason the identity of the original periblem caps and their constituent cells is more difficult to trace in the node, though the contour of the original cells can as a rule be recognized by the thickness of their walls (see Fig. 5).

It has already been indicated that the number of circles of air-canals is related to the number of layers of periblem, being one fewer; thus, in the specimen figured with five periblem caps there are four rings of canals (Fig. 3). In the older parts of the stem, however, additional rings can be observed, and it is in studying the modes of formation of these additional intercellular spaces that the part played by the plerome in contributing to the inner region of the cortex, including the endodermis, becomes clear.

It is necessary therefore to return and to consider in some detail the fate of the most internal layer of the periblem. As described above, the first dividing-wall runs tangentially across the cell from one air-canal to another (Fig. 3). Further segmentation takes place in the inner and larger of the two cells so formed, and in this the next wall is placed in an obliquely radial direction, with its outer end usually based upon an air-canal. Where the inner end of this wall intersects the wall of the outermost plerome cell a new intercellular space arises, and thus is initiated a fifth ring of air-canals (Fig. $4, a c{ }^{5}$ ). It is obvious that cells bounding these canals on the inner side must be derived from the plerome, and this can be readily confirmed. Moreover, it not infrequently happens that in the development of the fourth ring of air-canals the separating cell-walls of the two cells bounding it on its inner side may split apart, thus permitting the enlargement of a plerome cell which thus becomes the inner boundary of the canal. The whole plerome is at this stage actively enlarging, but the outermost cells divide for the most part by radial walls, and also increase in size in a tangential direction. They thus form a fairly well defined layer distinct from the rest of the plerome. Although no regular sequence can be traced in their divisions, they sooner or later divide by tangential walls into inner and outer cells (Fig. 6). This stage can be traced for some distance down the stem. Both layers may undergo subdivision by radial walls. The cells of the outer layer eventually enlarge and become rounded off as intercellular spaces develop between them. Eventually the cells of the inner layer undergo a tangential division, and the relative position of the two layers of cells so formed remains unaltered in the mature stem. The innermost layer is the endodermis, and later develops the cuticularized folded band on the radial walls.

Considerable variation may be seen from the process just described. Some of the divisions may be omitted or, in other cases, may be increased in number, but on the whole the general sequence of development in 
the outer part of the plerome is that described above, and thus normally three layers of the inner cortex, including the endodermis, take their origin from the outer plerome.

This conclusion agrees with that of Schoute, and is thus directly opposed to the earlier explanation given by Sanio, who considered that the

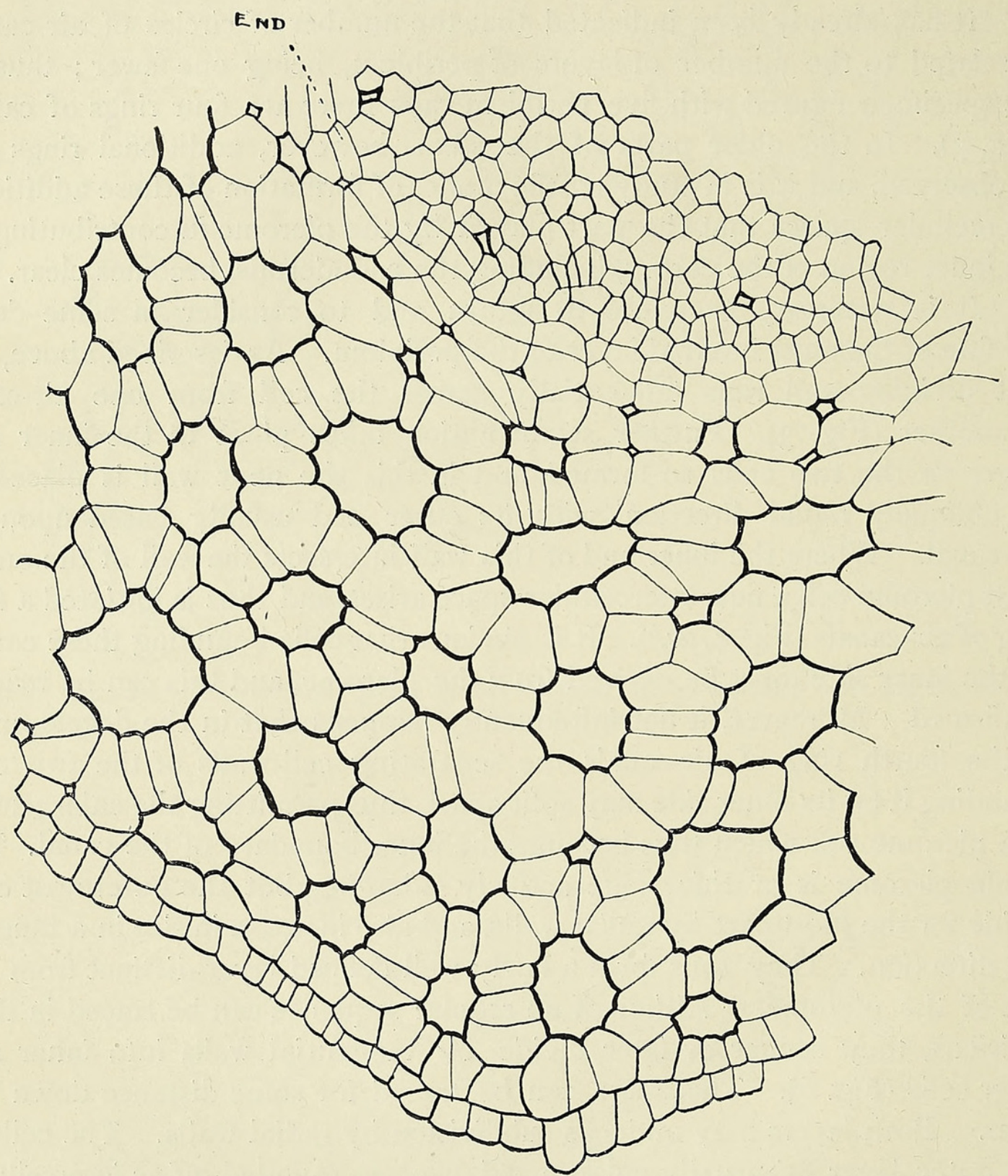

FIG. 6. Transverse section through older stem, showing the formation of the endodermis and final appearance of air-canals. end., endodermis.

three layers in question originated by the subdivision of the innermost layer of the periblem.

Although the observations do not coincide in exact detail with those of Schoute, this is probably to be accounted for by the fact that, owing to this investigation having been confined to this one species, it was possible to examine a large number of apices and thus to obviate the disadvantages 
connected with a description of one particular specimen. There is a wide variation in dimensions of the stem at the apex which is associated with differences in the number of periblem caps and bulk of the plerome. The number of the former may even vary in one and the same apex, as, for instance, in one specimen examined there were five caps on the one side of the stem and four on the other. The results of this investigation therefore confirm the observations of Schoute, and emphasize his conclusion that the endodermis cannot be regarded as a layer of definite morphological value. That is to say, its ontogenetic history is shown to be variable as elucidated by a study of cell-lineage. The only criterion of morphological identity in such instances would have to reside in the structure of the completely differentiated tissues, irrespective of their cellular history. This was, speaking generally, the position adopted by Van Tieghem, and whilst it illustrates the plasticity of the plant cells in differentiating into this or that form of tissue, it emphasizes the abstract character of the so-called morphology of the tissues themselves.

\section{REFERENCES.}

1. Schoute, J. C.: Die Stelar-Theorie. P. Noordhoff, Groningen, I902.

2. SAnıo, C. : Ueber endogene Gefässbündelbildung. Bot. Zeit., xxii Jahrgang, I864. 


\section{$2 \mathrm{BHL}$ Biodiversity Heritage Library}

Barratt, K. 1916. "The origin of the endodermis in the stem of Hippuris." Annals of botany 30, 91-99.

https://doi.org/10.1093/oxfordjournals.aob.a089590.

View This Item Online: https://www.biodiversitylibrary.org/item/237452

DOI: https://doi.org/10.1093/oxfordjournals.aob.a089590

Permalink: https://www.biodiversitylibrary.org/partpdf/320098

\section{Holding Institution}

Smithsonian Libraries

\section{Sponsored by}

Biodiversity Heritage Library

\section{Copyright \& Reuse}

Copyright Status: Not in copyright. The BHL knows of no copyright restrictions on this item.

This document was created from content at the Biodiversity Heritage Library, the world's largest open access digital library for biodiversity literature and archives. Visit BHL at https://www.biodiversitylibrary.org. 